\title{
Differential Expression of Cholecystokinin A Receptor in Gallbladder Cancer in the Young and Elderly Suggests Two Subsets of the Same Disease?
}

\author{
Hasan Raza Kazmi, ${ }^{1}$ Abhijit Chandra, ${ }^{1}$ Kavita Baghel, ${ }^{1}$ Anshuman Singh, ${ }^{2}$ Jaya Nigam, \\ Devendra Parmar, ${ }^{2}$ Abbas Ali Mahdi, ${ }^{3}$ Sudhir K. Goel, ${ }^{4}$ and Sandeep Kumar \\ ${ }^{1}$ Department of Surgical Gastroenterology, King George's Medical University, Lucknow 226003, India \\ ${ }^{2}$ Developmental Toxicology Division, Indian Institute of Toxicology Research, Lucknow 226003, India \\ ${ }^{3}$ Department of Biochemistry, King George's Medical University, Lucknow 226003, India \\ ${ }^{4}$ Department of Biochemistry, All India Institute of Medical Sciences, Bhopal, Madhya Pradesh 462024, India \\ ${ }^{5}$ All India Institute of Medical Sciences, Bhopal, Madhya Pradesh 462024, India \\ Correspondence should be addressed to Abhijit Chandra; abhijitchandra@hotmail.com
}

Received 28 February 2014; Revised 27 May 2014; Accepted 27 May 2014; Published 15 June 2014

Academic Editor: Saulius Butenas

Copyright (C) 2014 Hasan Raza Kazmi et al. This is an open access article distributed under the Creative Commons Attribution License, which permits unrestricted use, distribution, and reproduction in any medium, provided the original work is properly cited.

\begin{abstract}
Background. Cholecystokinin type A receptor (CCKAR) is known to be overexpressed in variety of human malignancies but information regarding its expression in gallbladder cancer (GBC) is limited. Attempts were now made to investigate expression pattern of CCKAR mRNA and protein in controls and GBC patients and correlate it with various clinicopathological parameters following surgical resection. Materials and Methods. Gallbladder tissue samples from 64 subjects (GBC: 39; control: 25) were studied. Expression of CCKAR mRNA was evaluated by reverse transcriptase-polymerase chain reaction and confirmed using real-time polymerase chain reaction. Protein expression was studied by enzyme-linked immunosorbent assay. Results. Significantly higher expression of CCKAR mRNA $(P<0.0001)$ and protein $(P<0.0001)$ was observed in GBC tissues. Overexpression was also observed for stage III and in moderately and poorly differentiated tumors. When the clinicopathological parameters were compared, we found age dependent decrease in CCKAR expression. Relatively higher expression of CCKAR was observed in younger patients (age $<45$ years) having more aggressive disease when compared with elderly ones (age $\geq 45$ years). Conclusions. Age related differential expression of CCKAR in GBC may suggest two possible variants of the disease in this endemic belt.
\end{abstract}

\section{Introduction}

Gallbladder cancer (GBC) is the most common malignancy of the biliary tract with high incidence in Chile, Japan, and Northern India (incidence rate of 7.4 per $10^{5}$ for females and 3.6 per $10^{5}$ for males in Delhi) [1-3]. Complete surgical resection remains the only potential curative treatment for this malignancy but with high recurrence rate. However, at the time of diagnosis most patients have unresectable disease and only about $20 \%$ of patients are suitable candidates for surgery $[4,5]$. Further, the 5 -year survival rate is just $15 \%$ for the resected cases $[6,7]$. Approach of in vivo targeting of human cancers through peptide receptors is gaining interest and hence screening novel therapeutic proteins remains subject of intense investigation [8]. Cholecystokinin (CCK) is a gastrointestinal peptidyl hormone which stimulates pancreatic exocrine secretion, gut motility, and gallbladder contraction. Action of CCK on the gallbladder is mediated by high affinity seven-transmembrane spanning CCK type A receptor (CCKAR) belonging to $\mathrm{G}$ protein-coupled receptor's family $[9,10]$. Decrease in CCK receptors may be involved in the pathogenesis of gallstone formation resulting in decreased gallbladder motility. It has been observed that gallstones are present in nearly $80 \%$ of patients with GBC 
$[11,12]$. Moreover, abnormal processing of CCKAR is found to be associated with gallstones and obesity [13]. Expression of CCKAR has also been detected in various human cancers, including pancreatic malignancy [14-16]. However, information regarding its expression in GBC is limited. We aimed to study the expression of CCKAR in gallbladder malignancy and correlate it with the clinical presentation, including association with stones, stage of disease, and outcomes.

\section{Materials and Methods}

2.1. Clinical Samples. The ethics committee of the institute approved the protocol, and informed consent was obtained from each patient before enrolment. All procedures were in accordance with the Declaration of Helsinki. Thirty-nine resected GBC tissue samples were obtained through extended cholecystectomy between May 2010 and August 2012. Only resected GBC patients confirmed by postoperative biopsy were included in the study. Staging was done according to the American Joint Committee on Cancer tumor node metastasis classification (TNM), 2010 [17]. Patients not amenable for a curative resection (with advanced malignancy) were excluded. Twenty-five normal gallbladder tissue specimens obtained through surgery (removed as part of choledochal cyst excision ( $n=12$ ), Whipple's pancreaticoduodenectomy $(n=9)$, or following hepatobiliary trauma $(n=4))$ were selected as controls. All control gallbladders were histopathologically normal. Although these tissues are referred to as normal gallbladder tissues, it is important to point out that they cannot be regarded as healthy normal specimens. However, this was the best possible way that normal control gallbladder could be obtained.

Tissue samples were taken in TRIzol (Invitrogen) and stored at $-80^{\circ} \mathrm{C}$ until used for analysis. RNA was isolated as per the protocol of the supplier and its purity was checked by running it in $1 \%$ agarose gel. Total RNA $(2 \mu \mathrm{g})$ was transcribed to cDNA using High-Capacity cDNA Reverse Transcription Kit (Applied Biosystems, USA).

2.2. Reverse Transcription-Polymerase Chain Reaction (RT$P C R)$ and Gel Electrophoresis. Table 1 represents primer sequences that were used for amplification. Normalization was carried out using housekeeping gene, beta actin. The PCR cycling conditions (for CCKAR) were of initial denaturation of $5 \mathrm{~min}$ at $94^{\circ} \mathrm{C}$, followed by 35 cycles at $94^{\circ} \mathrm{C}$ for $1 \mathrm{~min}$ and $60^{\circ} \mathrm{C}$ for $1 \mathrm{~min}$ and $72^{\circ} \mathrm{C}$ for $1 \mathrm{~min}$ and $30 \mathrm{~s}$, and final extension of $72^{\circ} \mathrm{C}$ for $10 \mathrm{~min}$. For beta actin, the PCR cycle conditions were of initial denaturation at $94^{\circ} \mathrm{C}$ for $5 \mathrm{~min}$, followed by 30 cycles at $94^{\circ} \mathrm{C}$ for $30 \mathrm{~s}, 58^{\circ} \mathrm{C}$ for $30 \mathrm{~s}$, and $72^{\circ} \mathrm{C}$ for $45 \mathrm{~s}$, and final extension of $72^{\circ} \mathrm{C}$ for 10 minutes. Gene Amp PCR system 9700 (Applied Biosystems, USA) was used for amplification and products were analysed in $2 \%$ agarose gel stained with ethidium bromide in VERSA DOC Imaging system, Model 1000 (Biorad, USA). Densitometric analysis of the PCR products was done using Quantity One Quantitation Software version 4.3.1 (Biorad, USA).
2.3. Real-Time PCR Analysis. Real-time PCR assay reaction was conducted using 26 Power SYBR Green PCR master mix (Applied Biosystems, USA) as described earlier by Baghel et al. [24]. Through the use of human CCKAR sequences obtained from the GenBank database, primer sets were designed by using the software primer express 3.0 (ABI, USA). After comparison, the potential primer sets were identified. The specificity of the primers was then validated using sequencing. Melting curve profile obtained using the dissociation software of the real-time PCR apparatus also validated the specificity of the primer design. For each sample, PCR reaction was performed in triplicate. 7900HT Sequence Detector System software version 2.2.1 (Applied Biosystems, USA) was used to analyze the data.

2.4. ELISA. Expression of CCKAR protein was determined quantitatively using CCKAR antibody (Santa Cruz, USA). Initially, standard curve was plotted with known concentrations of antigen $(0.312 \mathrm{ng} / \mathrm{mg}-60 \mathrm{ng} / \mathrm{mg})$. In brief, 96well immunoassay plates were coated with $100 \mu \mathrm{L} /$ well of diluted antigen for 2 hours followed by blocking step with blocking solution ( $1 \%$ BSA). Plates were incubated overnight with $100 \mu \mathrm{L} /$ well of diluted (1:1000) anti-human CCKAR antibody at $4^{\circ} \mathrm{C}$. After washing away any unbound antibody, $100 \mu \mathrm{L} /$ well of secondary antibody (1:2000) was added, and incubation was done for 3 hours. This was followed by dispensation of $100 \mu \mathrm{L}$ /well of substrate solution (Super Signal ELISA Pico, Thermo Scientific). The enzymesubstrate reaction was stopped after sufficient colour development by adding $50 \mu \mathrm{L} /$ well of $0.5 \mathrm{M} \mathrm{H}_{2} \mathrm{SO}_{4}$. Colour change was measured spectrophotometrically at a wavelength of $450 \mathrm{~nm}$.

2.5. Statistical Analysis. Statistical analysis was carried out using unpaired Student's $t$-test. $P<0.05$ (two-tailed) was considered to be statistically significant. Correlation analysis was performed using Pearson correlation method. Clinical data was analyzed using Fisher exact or Chi-square test.

\section{Results}

Characteristic profiles of subjects enrolled in the study are shown in Table 2. Significant increase $(23.27 \%, P<0.0001)$ of CCKAR mRNA in GBC tissues was observed as compared with controls. The band size for CCKAR mRNA was $375 \mathrm{bp}$ and that of beta actin was $175 \mathrm{bp}$ (Figure 1). Further, stratification of band intensity in relation to the stage of tumor revealed significant increase $(13.23 \%, P<0.0001)$ in expression of CCKAR mRNA in stage III as compared with stage II GBC. Quantitative real-time PCR assay also revealed significantly higher $(63.67 \%, P<0.0001)$ expression of CCKAR mRNA in GBC tissues (Figure 2). Higher expression $(26.94 \%, P<0.0001)$ of CCKAR mRNA was observed in stage III as compared with stage II tumor. Increased expression $(22.83 \%, P<0.001)$ of CCKAR mRNA was observed for moderately and poorly differentiated tissues as compared with well-differentiated ones. However, no significant 


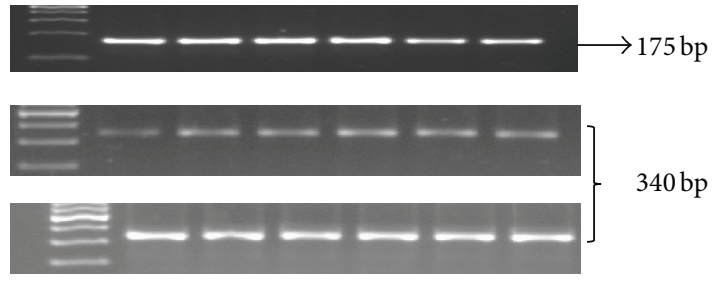

(a)
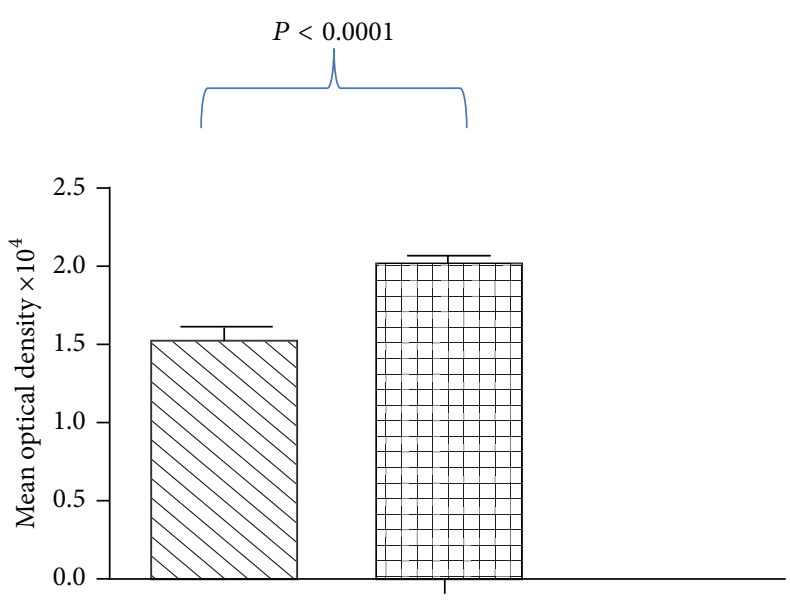

$$
\begin{aligned}
& \square \text { Control (normal) }
\end{aligned}
$$

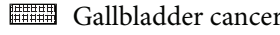

(b)

FIGURE 1: (a) Reverse transcription-polymerase chain reaction products of CCKAR mRNA in control gallbladder (middle row) and gallbladder cancer (lower row) tissues after normalization with housekeeping gene beta actin (upper row). DNA ladder is of $100 \mathrm{bp}$. (b) Graphical representation of mean band density of CCKAR PCR product in control gallbladder and gallbladder cancer. Data is represented as mean \pm standard error. CCKAR: cholecystokinin type A receptor and PCR: polymerase chain reaction.

TABLE 1: Primer sequences used for amplification of CCKAR and beta actin in RT-PCR and real-time PCR. CCKAR: cholecystokinin type A receptor and RT-PCR: reverse transcription-polymerase chain reaction.

\begin{tabular}{|c|c|c|c|}
\hline Gene & Technique & Primer sequence & First author \\
\hline CCKKAR & RT-PCR & $\begin{array}{c}\text { Forward 5' CCTACGACACCGCCTCCGC } 3^{\prime} \\
\text { Reverse } 5^{\prime} \text { TCCGTTCTTTCTTCTCTGCCTCCT } 3^{\prime}\end{array}$ & Mandair [18] \\
\hline Beta actin & Real-time PCR & $\begin{array}{l}\text { Forward 5' CCTGGCACCCAGCACAAT 3' } \\
\text { Reverse 5 } 5^{\prime} \text { GCCGATCCACACGGAGTACT } 3^{\prime}\end{array}$ & \\
\hline CCKKAR & Real-time PCR & $\begin{array}{l}\text { Forward 5' GCGATTTGCAAACCCTTACAG } 3^{\prime} \\
\text { Reverse } 5^{\prime} \text { CACCTTCAAAGCATGGGATTTT } 3^{\prime}\end{array}$ & - \\
\hline
\end{tabular}

TABLE 2: Characteristics of controls and gallbladder cancer (GBC) patients.

\begin{tabular}{lcc}
\hline Parameters & Normal, $n(\%)$ & GBC, $n(\%)$ \\
\hline Total & $\mathbf{2 5}$ & $\mathbf{3 9}$ \\
Male & $11(44)$ & $12(30.77)$ \\
Female & $14(56)$ & $27(69.23)$ \\
Mean age (years) \pm S.D. & $41.24 \pm 13.27$ & $43.87 \pm 12.39$ \\
$\quad$ Range & $19-63$ & $21-65$ \\
Presence of gallstones & 0 & $28(71.79)$ \\
Stage & $\mathrm{N}^{\mathrm{a}} \mathrm{A}^{\mathrm{a}}$ & \\
$\quad$ II & & $22(56.41)$ \\
$\quad$ III & & $17(43.59)$ \\
Tumor differentiation & $\mathrm{N} / \mathrm{A}^{\mathrm{a}}$ & \\
$\quad$ Poorly and moderately & & $20(51.28)$ \\
$\quad$ Well & & $19(48.72)$ \\
\hline
\end{tabular}

${ }^{\mathrm{a}} \mathrm{N} / \mathrm{A}$ : not applicable.

difference in expression was found for presence or absence of gallstones $(P=0.98)$.
Significant correlation between CCKAR mRNA expression and age of GBC patients was observed, when relative quantification (by real-time PCR) was correlated with various clinicopathological parameters. We selected 12 GBC patients and 12 age and sex matched controls (for normalization in real-time PCR) from our enrolled patients and an age dependent decrease in the CCKAR mRNA expression was observed. The correlation was significant at 0.01 level (2-tailed) with Pearson correlation coefficient, $r=-0.956$ (Figure 3). As there was a marked decrease in the relative quantification after 45 years of age, we classified the GBC patient pool into two groups ( $\mathrm{A}=$ age $<45$ years $(n=6)$; $\mathrm{B}=$ age $\geq 45$ years $(n=6)$ ). Significantly higher expression (33.63\%, $P=0.004)$ of CCKAR mRNA was observed in group A as compared to B (Figure 4). There were 17 GBC patients below age of 45 years while the rest $(n=22)$ of recruited subjects were above or equal to the age of 45 years. Tables 3 and 4 represent age-wise distribution of clinical presentation and histopathological parameters, respectively, for all GBC patients. The mean survival was significantly shorter in GBC patients with age $<45$ years as compared to patients with age $\geq 45$ years. The distribution of stage of tumor was 
TABLE 3: Table showing clinical presentation of GBC patient for age $<45$ years $(n=17)$ and age $\geq 45$ years $(n=22)$.

\begin{tabular}{lccc}
\hline Parameters & $\begin{array}{c}\text { Age }<45 \text { years } \\
(n=17)\end{array}$ & $\begin{array}{c}\text { Age } \geq 45 \text { years } \\
(n=22)\end{array}$ & $c(\%)$ \\
& $n(\%)$ & $19(86.36)$ & 0.62 \\
Abdominal pain & $16(94.12)$ & $20(90.91)$ & 0.49 \\
Weight loss & $17(100)$ & $3(13.64)$ & $0.01^{*}$ \\
Palpable lump & $9(52.94)$ & $14(63.64)$ & 0.29 \\
Presence of gallstones & $14(82.35)$ & $14.08 \pm 5.09$ & $0.034^{*}$ \\
Survival in months \pm S.D. & $10.3 \pm 3.18$ & & \\
\hline
\end{tabular}

Values are given as numbers. Differences were tested by using Fisher exact test. ${ }^{*}$ Indicates statistically significant difference $(P<0.05)$. GBC: gallbladder cancer.

TABLE 4: Comparison of histopathological parameters and tumor stage of gallbladder cancer patients between age $<45$ years $(n=17)$ and age $\geq 45$ years $(n=22)$.

\begin{tabular}{lcc}
\hline Parameters & $\begin{array}{c}\text { Age }<45 \text { years } \\
(n=17) \\
n(\%)\end{array}$ & $\begin{array}{c}\text { Age } \geq 45 \text { years } \\
(n=22) \\
n(\%)\end{array}$ \\
\hline Histopathology & & $15(68.18)$ \\
$\quad$ Well-differentiated tumors & $4(23.53)$ & $7(31.82)$ \\
$\quad$ Poorly and moderately differentiated tumors & $13(76.47)$ & $15(65)$ \\
Tumor stage & & $0.01^{*}$ \\
$\quad$ Stage II & $7(36.36)$ & $7(35)$ \\
$\quad$ Stage III & $10(63.64)$ & 0.11 \\
\hline
\end{tabular}

Values are given as numbers. Differences were tested by using Fisher exact test. ${ }^{*}$ Indicates statistically significant difference $(P<0.05)$.

found to be insignificant $(P=0.11)$ between age $\geq 45$ years and age $<45$ years while significant difference $(P=0.01)$ was observed for cellular differentiation between both groups.

At translational level, mean CCKAR protein concentrations were significantly higher $(P<0.0001)$ in GBC patients as compared to controls. Significantly higher $(P=0.03)$ CCKAR protein content was observed for stage III as compared with stage II GBC and for poorly and moderately differentiated tumors as compared with well-differentiated ones $(P=0.03)$. We observed significant increase $(P<0.0001)$ of mean CCKAR protein content in GBC patients with age $<45$ years as compared with age $\geq 45$ years. However, there was no significant difference in CCKAR protein content for presence or absence of gallstones for GBC patients $(P=0.92)$.

\section{Discussion}

CCK is an important gut hormone which regulates growth of various gastrointestinal malignancies along with normal tissues [25]. CCK receptors in the normal human gallbladder have been studied [26-28], and its expression has also been reported in various human malignancies (Table 5). Due to selective expression, CCKAR may serve as potential biomarker for pancreatic adenocarcinoma [21]. However, in GBC CCKAR mRNA and protein expression has not been extensively studied. CCKAR is known to be involved in the main pathway for gallbladder contraction and association of gallstones with GBC is also known $[1,27]$. In a recent study, expression profile of CCKAR in GBC and gallstone disease by immunohistochemistry and immunoblotting was investigated, but its correlation with normal gallbladder was not studied [23]. In the present study, we analyzed CCKAR mRNA and protein expression in normal (control) gallbladder and GBC tissues. To the best of our knowledge, this is the first study evaluating expression of CCKAR at both transcriptional and translational levels in resected GBC.

Various studies reported the mean age of GBC presentation around 65 years with female preponderance [29-31]. However, studies from the Indian subcontinent show mean age to be 55 years $[23,32]$. In our study, the mean age of GBC patients was 43.87 years with male to female ratio of $1: 2.87$. The early presentation in this endemic area is maybe due to early exposure to the risk factors.

Overexpression of CCKAR mRNA and protein in GBC tissues is the most relevant finding of this study. A significant age dependent decrease in CCKAR expression became evident with younger patients (age $<45$ years) having higher expression of CCKAR as compared with elderly ones (age $\geq$ 45 years). Our data also showed that patients in the younger age presented more frequently with poorly and moderately differentiated tumors suggesting more advanced presentation of the disease. Survival after surgical resection of the younger GBC patients was found to be significantly less as compared with the elderly. The difference in clinical presentation along with differential CCKAR expression in GBC patients suggests two variants of the disease in this endemic belt with younger patients (age $<45$ years) having more aggressive disease, poor surgical outcomes, and higher CCKAR expression in 


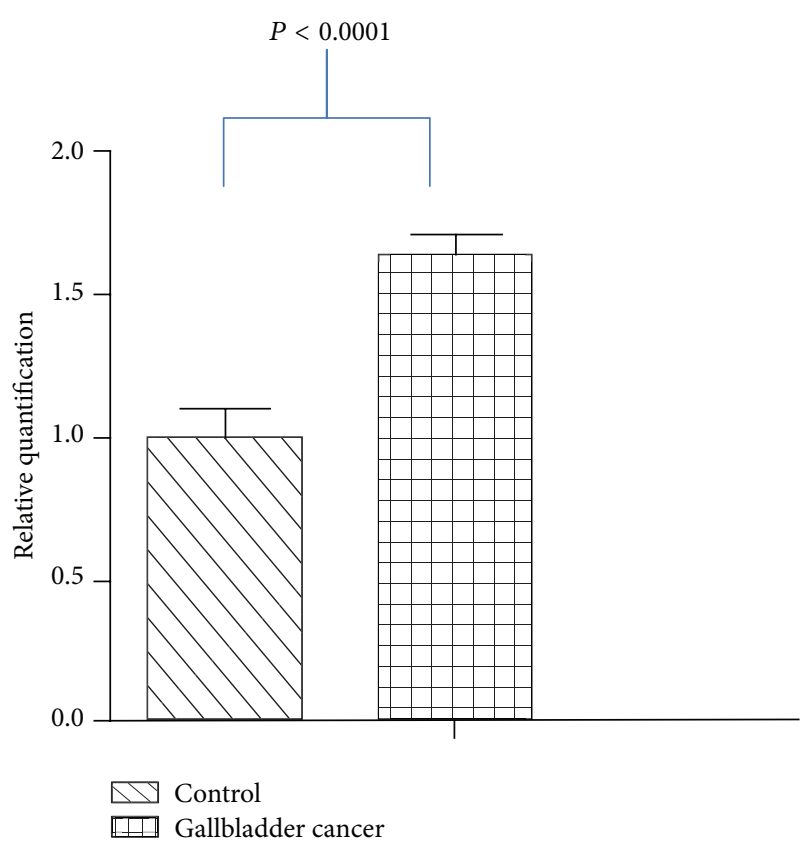

FIGURE 2: Graphical representation of CCKAR mRNA expression in gallbladder cancer tissues by real-time PCR. All the values are mean \pm standard error. CCKAR: cholecystokinin type A receptor and PCR: polymerase chain reaction.

comparison to elderly group (age $\geq 45$ years) having more indolent disease, better outcomes, and decreased CCKAR expression. Differential expression of CCKAR mRNA was also observed for tumor stage and differentiation. Rai et al. [23] found insignificant difference in the expression of CCKAR protein between various grades of tumor. This difference may be attributed to the method of detecting protein expression in both studies.

Limited information is available regarding expression of CCKAR protein in malignant tissues [20, 22, 23]. Most of the studies carried out so far were based on semiquantitative technique of immunohistochemistry or immunoblotting [22, 23]. In the present study, overexpression of CCKAR was observed in GBC indicating similar influence of CCK and its receptor in origin and growth of gallbladder malignancy. Our current findings are in line with the results of a previous study done so far [23]. Schaffer et al. [33] observed that multiple naturally occurring amino acid polymorphisms and/or mutations in transmembrane domain of CCK receptor in Mastomys natalensis may together result in ligandindependent CCK receptor overactivity which may lead to the development of tumor. Takata et al. [34] demonstrated that region downstream of -622 in the promoter region might regulate human CCKAR transcription. Differential expression of this receptor may be due to polymorphisms or mutation in the promoter or coding region which correlates with gene expression in the human gallbladder and needs further evaluation $[34,35]$.

We studied the expression of CCKAR mRNA and protein in resected stages II and III GBC tissues. In our recruited GBC patients, none were of stage I, as such cases are usually

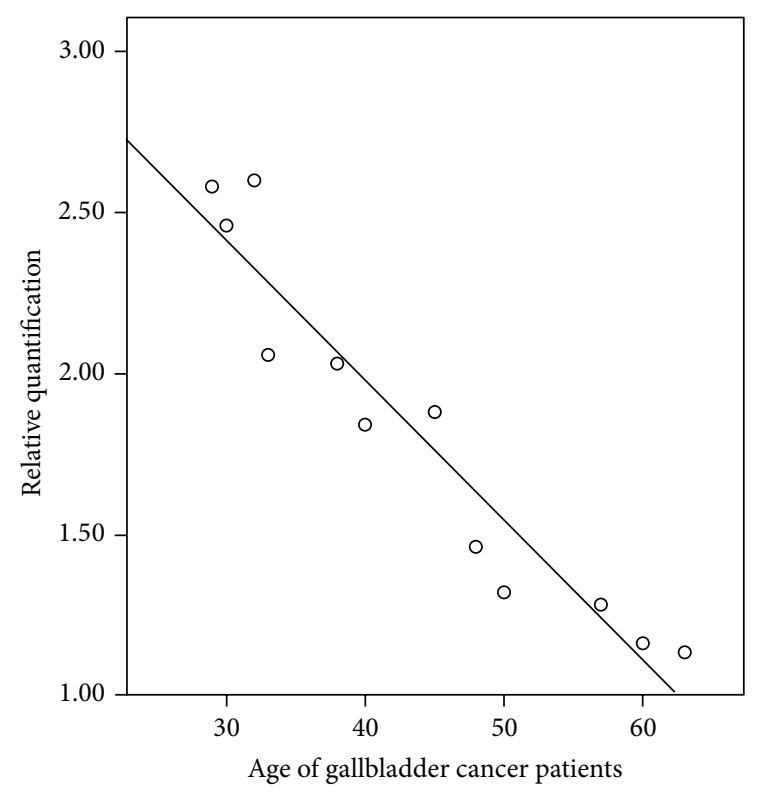

FIGURE 3: Scatter diagram showing correlation between relative quantification of cholecystokinin A receptor mRNA expression and age of gallbladder cancer patients. Correlation is significant at 0.01 level (2-tailed) with Pearson correlation coefficient, $r=-0.956$.

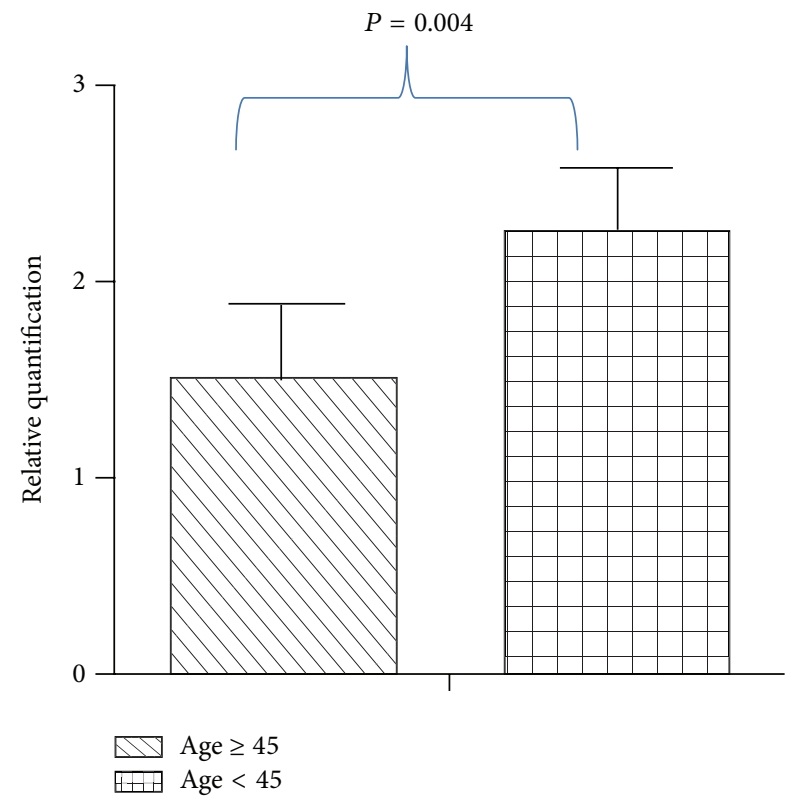

FIGURE 4: Comparison of relative quantification of cholecystokinin A receptor mRNA expression between age $\geq 45$-year $(n=6)$ and age $<45$-year $(n=6)$ human gallbladder cancer patients.

detected incidentally during cholecystectomy performed for benign diseases. Additional stagewise studies are required along with dysplasia samples to establish its role in gallbladder carcinogenesis. Also, investigation of age dependent change of CCKAR expression needs to be explored in much larger samples along with multivariable analysis and may be the area of future research. 
TABLE 5: CCKAR expression profile in human malignancies: literature review. CCKAR: cholecystokinin type A receptor.

\begin{tabular}{|c|c|c|c|c|}
\hline First author & Tumour types & Number of samples & Methodology & Findings \\
\hline Okada [19] & Gastric & 14 & RT-PCR & $\begin{array}{l}\text { Suggest a greater role for } \\
\text { CCK and CCKAR than for } \\
\text { gastrin and CCK-B } \\
\text { receptor in gastric cancers }\end{array}$ \\
\hline Clerc [15] & $\begin{array}{l}\text { Oesophageal, } \\
\text { gastric, and } \\
\text { colon cancer }\end{array}$ & $\begin{array}{l}\text { 8: oesophageal } \\
\text { 12: colon } \\
\text { 8: gastric }\end{array}$ & RT-PCR & $\begin{array}{l}\text { The expression of CCKAR } \\
\text { may be an important } \\
\text { indicator of the influence of } \\
\text { CCK on the origin and } \\
\text { growth of these cancers }\end{array}$ \\
\hline Reubi [20] & $\begin{array}{l}\text { Various human } \\
\text { malignancies }\end{array}$ & $\begin{array}{l}\text { 32: gastroenteropancreatic } \\
\text { tumour } \\
\text { 24: medullary thyroid } \\
\text { carcinoma } \\
\text { 16: neuroblastoma } \\
\text { 27: meningioma } \\
\text { 65: breast carcinoma }\end{array}$ & Receptor autoradiography & $\begin{array}{l}\text { CCKAR rarely expressed in } \\
\text { tumors except } \\
\text { gastroenteropancreatic } \\
\text { tumors } \\
(38 \%), \text { meningiomas } \\
(30 \%) \text {, and some } \\
\text { neuroblastomas }(19 \%)\end{array}$ \\
\hline Weinberg [21] & $\begin{array}{c}\text { Pancreatic } \\
\text { cancer }\end{array}$ & 22 & RT-PCR & $\begin{array}{l}\text { Overexpression of CCKAR } \\
\text { mRNA in pancreatic cancer }\end{array}$ \\
\hline Moonka [16] & $\begin{array}{l}\text { Pancreatic } \\
\text { cancer }\end{array}$ & 30 & RT-PCR & $\begin{array}{l}\text { Increased expression of } \\
\text { CCKAR mRNA may } \\
\text { stimulate pancreatic cancer }\end{array}$ \\
\hline Schulz [22] & $\begin{array}{l}\text { Various human } \\
\text { tumours }\end{array}$ & $\begin{array}{l}\text { 5: colorectal } \\
\text { 5: pancreatic } \\
\text { adenocarcinoma } \\
\text { 5: breast } \\
\text { 10: ovarian } \\
\text { 4: prostate } \\
\text { 6: thyroid } \\
\text { 15: carcinoid } \\
\text { 8: pancreatic insulinoma } \\
\text { 4: pituitary adenoma } \\
\text { 4: pheochromocytoma } \\
\text { 4: glioblastoma } \\
\text { 4: meningioma }\end{array}$ & IHC & $\begin{array}{l}\text { CCKAR overexpression in } \\
\text { a subset of human } \\
\text { neuroendocrine tumours } \\
\text { may provide a molecular } \\
\text { basis for efficient targeting } \\
\text { of these tumors with } \\
\text { radiolabeled CCK analogs }\end{array}$ \\
\hline Rai [23] & $\begin{array}{l}\text { Gallbladder } \\
\text { cancer }\end{array}$ & 94 & $\mathrm{IHC}$ & $\begin{array}{l}\text { Significant increase in } \\
\text { expression of CCKAR in } \\
\text { gallbladder cancer as } \\
\text { compared to gallstone } \\
\text { disease }\end{array}$ \\
\hline Current study & $\begin{array}{l}\text { Gallbladder } \\
\text { cancer }\end{array}$ & 31 resected samples & RT-PCR, real-time PCR, and ELISA & $\begin{array}{l}\text { Overexpression of CCKAR } \\
\text { mRNA and protein in GBC } \\
\text { tissues as compared with } \\
\text { normal gallbladder suggests } \\
\text { its therapeutic potential }\end{array}$ \\
\hline
\end{tabular}

RT-PCR: reverse transcriptase-polymerase chain reaction and IHC: immunohistochemistry.

Due to overexpression in many primary human cancers, peptides and peptide receptors remain an interesting candidate for treating cancers through receptor targeting approach [36]. Large body of data exists concerningseveral peptide and nonpeptidyl CCKAR modulators, and clinical potentials of these agents are under trial [37]. Our study defines two possible variants of GBC in this endemic belt. It also forms the basis for developing newer therapeutic options based on the CCKAR active drugs to obtain better outcomes following surgery in these variants.

\section{Conclusions}

We conclude that younger patients of gallbladder malignancy with higher expression of CCKAR have more aggressive disease and short survival as compared with elder ones. This 
differential expression of CCKAR reflects two subsets of GBC in North Indian population which needs to be evaluated further using larger sample size.

\section{Disclosure}

A part of this paper was presented in the 10th Annual Conference of Indian Chapter of International HepatoPancreato-Biliary Association (IHPBA), February 15-17, 2013, Coimbatore, India.

\section{Conflict of Interests}

The authors declare that they have no conflict of interests regarding the publication of this paper.

\section{Acknowledgments}

The present work was supported by the Council of Science and Technology, Lucknow, Uttar Pradesh, India (Grant no. CST/SERPD/D-3429), and the Indian Council of Medical Research, New Delhi, India (Grant no. 3/2/2/60/2011/NCDIII).

\section{References}

[1] S. Misra, A. Chaturvedi, N. C. Misra, and I. D. Sharma, "Carcinoma of the gallbladder," The Lancet Oncology, vol. 4, no. 3, pp. 167-176, 2003.

[2] V. K. Kapoor and A. J. McMichael, "Gallbladder cancer: an "Indian" disease," National Medical Journal of India, vol. 16, no. 4, pp. 209-213, 2003.

[3] N. S. Murthy, D. Rajaram, and M. Gautam, "Trends in incidence of gallbladder cancer-Indian scenario," Gastrointestinal Cancer: Targets and Therapy, vol. 2011, no. 1, pp. 1-9, 2011.

[4] E. A. Shaffer, "Gallbladder cancer: the basics," Gastroenterology and Hepatology, vol. 4, no. 10, pp. 737-741, 2008.

[5] A. X. Zhu, T. S. Hong, A. F. Hezel, and D. A. Kooby, "Current management of gallbladder carcinoma," Oncologist, vol. 15, no. 2, pp. 168-181, 2010.

[6] K. Kim, E. K. Chie, J. Y. Jang et al., "Postoperative chemoradiotherapy for gallbladder cancer," Strahlentherapie und Onkologie, vol. 188, no. 5, pp. 388-392, 2012.

[7] C. Verslype, H. Prenen, and E. Van Cutsem, "The role of chemotherapy in biliary tract carcinoma," $H P B$, vol. 10, no. 3, pp. 164$167,2008$.

[8] J. C. Reubi, "Peptide receptors as molecular targets for cancer diagnosis and therapy," Endocrine Reviews, vol. 24, no. 4, pp. 389-427, 2003.

[9] C. Tang, I. Biemond, and C. B. H. W. Lamers, "Cholecystokinin receptors in human pancreas and gallbladder muscle: a comparative study," Gastroenterology, vol. 111, no. 6, pp. 1621-1626, 1996.

[10] A. Srivastava, S. N. Pandey, M. Dixit, G. Choudhuri, and B. Mittal, "Cholecystokinin receptor a gene polymorphism in gallstone disease and gallbladder cancer," Journal of Gastroenterology and Hepatology, vol. 23, no. 6, pp. 970-975, 2008.
[11] J. R. Upp Jr., W. H. Nealon, P. Singh et al., "Correlation of cholecystokinin receptors with gallbladder contractility in patients with gallstones," Annals of Surgery, vol. 205, no. 6, pp. 641-648, 1987.

[12] H. R. Kazmi, A. Chandra, J. Nigam, M. Noushif, D. Parmar, and V. Gupta, "Prognostic significance of k-ras codon 12 mutation in patients with resected gallbladder cancer," Digestive Surgery, vol. 30, no. 3, pp. 233-239, 2013.

[13] L. J. Miller, E. L. Holicky, C. D. Ulrich, and E. D. Wieben, "Abnormal processing of the human cholecystokinin receptor gene in association with gallstones and obesity," Gastroenterology, vol. 109, no. 4, pp. 1375-1380, 1995.

[14] G. S. Baldwin and A. Shulkes, "CCK receptors and cancer," Current Topics in Medicinal Chemistry, vol. 7, no. 12, pp. 1232-1238, 2007.

[15] P. Clerc, M. Dufresne, C. Saillan et al., "Differential expression of the CCK-A and CCK-B/gastrin receptor genes in human cancers of the esophagus, stomach and colon," International Journal of Cancer, vol. 72, no. 6, pp. 931-936, 1997.

[16] R. Moonka, W. Zhou, and R. H. Bell Jr., "CholecystokininA receptor messenger RNA expression in human pancreatic cancer," Journal of Gastrointestinal Surgery, vol. 3, no. 2, pp. 134$140,1999$.

[17] S. B. Edge and C. C. Compton, "The american joint committee on cancer: the 7th edition of the AJCC cancer staging manual and the future of TNM," Annals of Surgical Oncology, vol. 17, no. 6, pp. 1471-1474, 2010.

[18] K. K. Mandair, P. Towner, I. F. Stamford et al., "Cholecystokinin receptors in human pancreatic cancer cell lines," European Journal of Cancer, vol. 34, no. 9, pp. 1455-1459, 1998.

[19] N. Okada, A. Kubota, T. Imamura et al., "Evaluation of cholecystokinin, gastrin, CCK-A receptor, and CCK-B/gastrin receptor gene expressions in gastric cancer," Cancer Letters, vol. 106, no. 2, pp. 257-262, 1996.

[20] J. C. Reubi, J.-C. Schaer, and B. Waser, "Cholecystokinin (CCK)$\mathrm{A}$ and CCK-B/gastrin receptors in human tumors," Cancer Research, vol. 57, no. 7, pp. 1377-1386, 1997.

[21] D. S. Weinberg, B. Ruggeri, M. T. Barber, S. Biswas, S. Miknyocki, and S. A. Waldman, "Cholecystokinin A and B receptors are differentially expressed in normal pancreas and pancreatic adenocarcinoma," Journal of Clinical Investigation, vol. 100, no. 3, pp. 597-603, 1997.

[22] S. Schulz, C. Röcken, C. Mawrin, and S. Schulz, "Immunohistochemical localization of CCK1 cholecystokinin receptors in normal and neoplastic human tissues," Journal of Clinical Endocrinology and Metabolism, vol. 90, no. 11, pp. 6149-6155, 2005.

[23] R. Rai, M. Tewari, M. Kumar, T. B. Singh, and H. S. Shukla, "Expression profle of cholecystokinin type-a receptor in gallbladder cancer and gallstone disease," Hepatobiliary and Pancreatic Diseases International, vol. 10, no. 4, pp. 408-414, 2011.

[24] K. Baghel, H. R. Kazmi, S. Raj, A. Chandra, and R. N. Srivastava, "Elevated expression of maspin mRNA as a predictor of survival in stage II and III gallbladder cancer cases," Asian Pacific Journal of Cancer Prevention, vol. 15, no. 1, pp. 343-347, 2014.

[25] R. P. Thomas, M. R. Hellmich, C. M. Townsend Jr., and B. M. Evers, "Role of gastrointestinal hormones in the proliferation of normal and neoplastic tissues," Endocrine Reviews, vol. 24, no. 5, pp. 571-599, 2003. 
[26] C. Tang, I. Biemond, and C. B. H. W. Lamers, "Cholecystokinin receptors in human pancreas and gallbladder muscle: a comparative study," Gastroenterology, vol. 111, no. 6, pp. 1621-1626, 1996.

[27] Y. Tokunaga, K. L. Cox, R. Coleman, W. Concepcion, P. Nakazato, and C. O. Esquivel, "Characterization of cholecystokinin receptors on the human gallbladder," Surgery, vol. 113, no. 2, pp. 155-162, 1993.

[28] A. C. Ivy and A. Oldberg, "A hormone mechanism for gallbladder contraction and evacuation," American Journal of Physiology, vol. 86, pp. 599-613, 1928.

[29] J. Kim, K. T. Jang, K. H. Kim et al., "Aberrant maspin expression is involved in early carcinogenesis of gallbladder cancer," Tumor Biology, vol. 31, no. 5, pp. 471-476, 2010.

[30] Y. N. Silk, H. O. Douglass Jr., H. R. Nava, D. L. Driscoll, and G. Tartarian, "Carcinoma of the gallbladder. The Roswell Park experience," Annals of Surgery, vol. 210, no. 6, pp. 751-757, 1989.

[31] T. Takahashi, N. Shivapurkar, E. Riquelme et al., "Aberrant promoter hypermethylation of multiple genes in gallbladder carcinoma and chronic cholecystitis," Clinical Cancer Research, vol. 10, no. 18, part 1, pp. 6126-6133, 2004.

[32] P. Gupta, A. Agarwal, V. Gupta, P. K. Singh, C. Pantola, and S. Amit, "Expression and clinicopathological significance of estrogen and progesterone receptors in gallbladder cancer," Gastrointestinal Cancer Research, vol. 5, no. 2, pp. 41-47, 2012.

[33] K. Schaffer, E. W. McBride, M. Beinborn, and A. S. Kopin, "Interspecies polymorphisms confer constitutive activity to the mastomys cholecystokinin-B/gastrin receptor," The Journal of Biological Chemistry, vol. 273, no. 44, pp. 28779-28784, 1998.

[34] Y. Takata, S. Takeda, T. Kawanami et al., "Promoter analysis of human cholecystokinin type-A receptor gene," Journal of Gastroenterology, vol. 37, no. 10, pp. 815-820, 2002.

[35] N. Sato, K. Miyasaka, S. Suzuki et al., "Lack of cholecystokininA receptor enhanced gallstone formation: a study in CCK-A receptor gene Knockout mice," Digestive Diseases and Sciences, vol. 48, no. 10, pp. 1944-1947, 2003.

[36] J. C. Reubi, "Peptide receptors as molecular targets for cancer diagnosis and therapy," Endocrine Reviews, vol. 24, no. 4, pp. 389-427, 2003.

[37] E. E. Cawston and L. J. Miller, "Therapeutic potential for novel drugs targeting the type 1 cholecystokinin receptor," British Journal of Pharmacology, vol. 159, no. 5, pp. 1009-1021, 2010. 


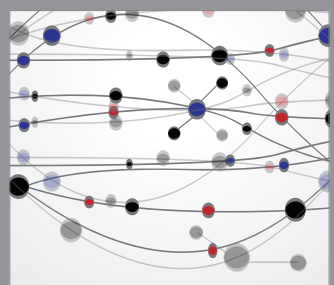

The Scientific World Journal
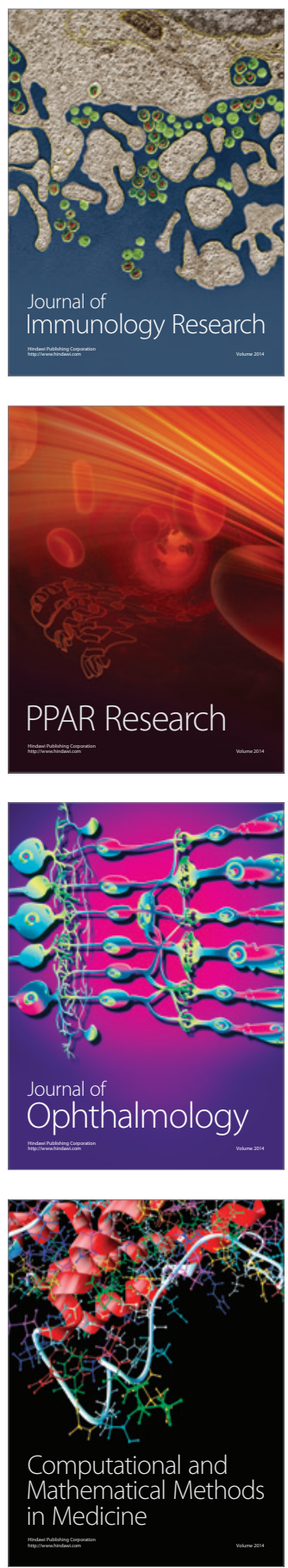

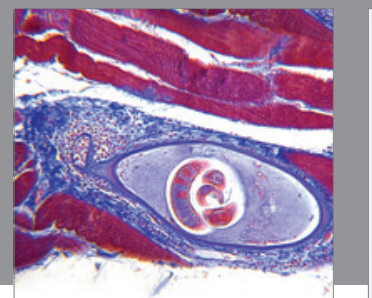

Gastroenterology

Research and Practice
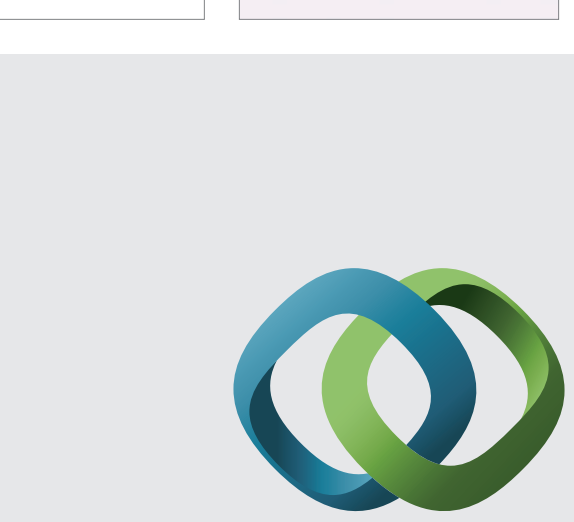

\section{Hindawi}

Submit your manuscripts at

http://www.hindawi.com
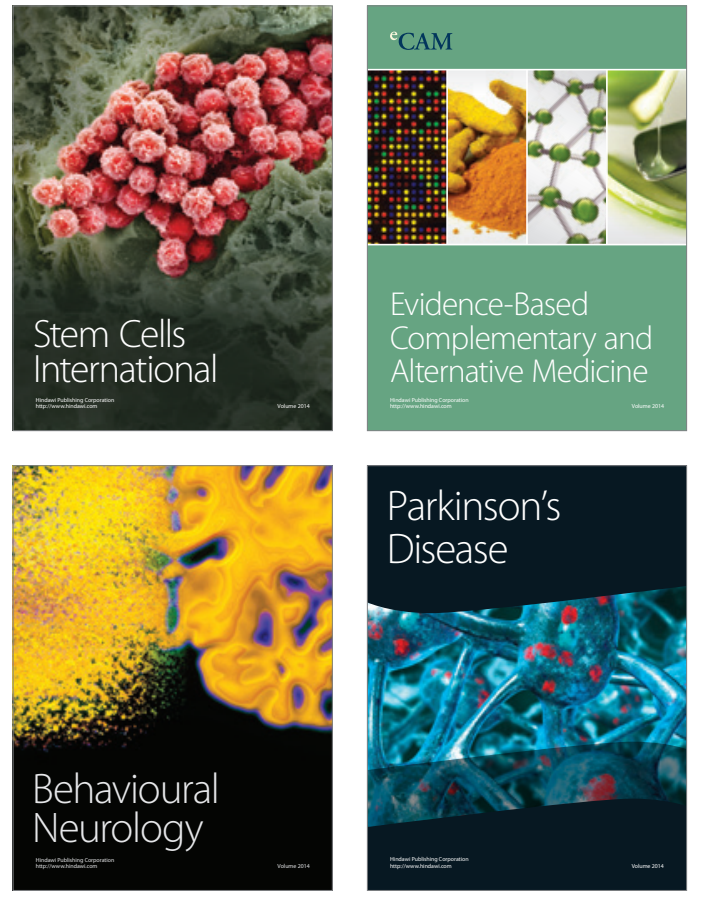
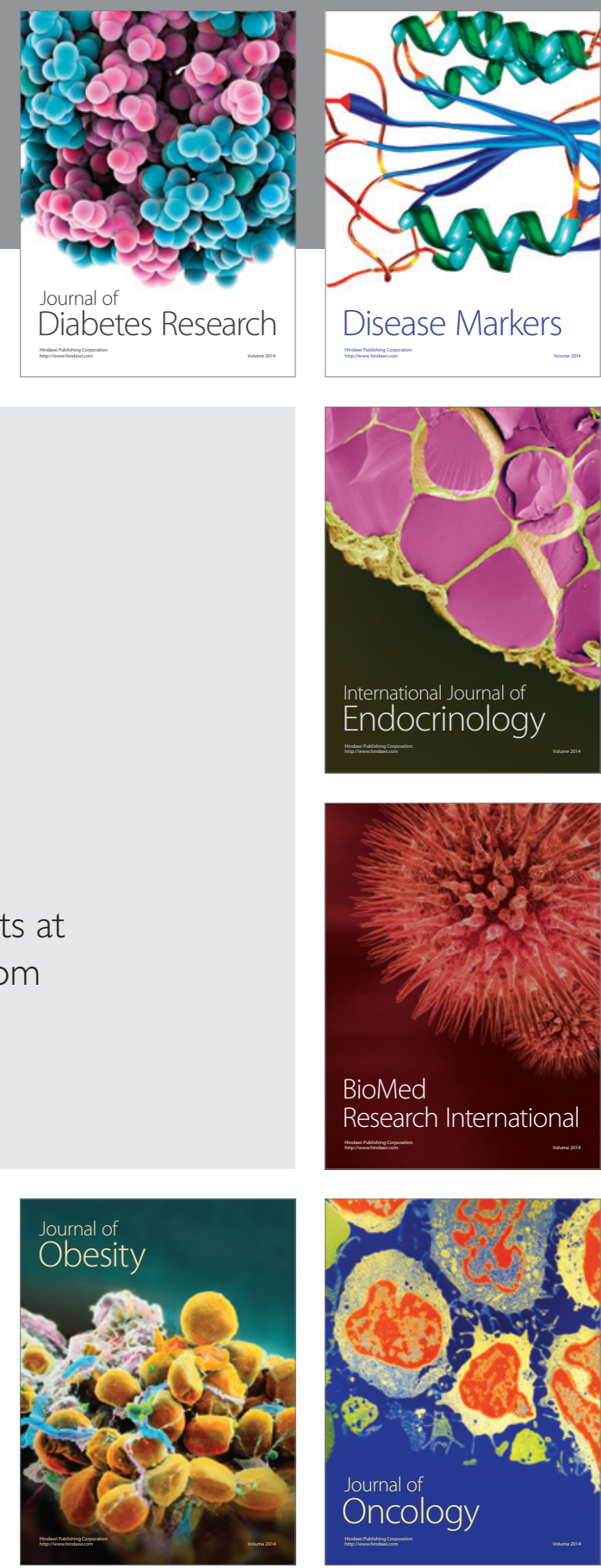

Disease Markers
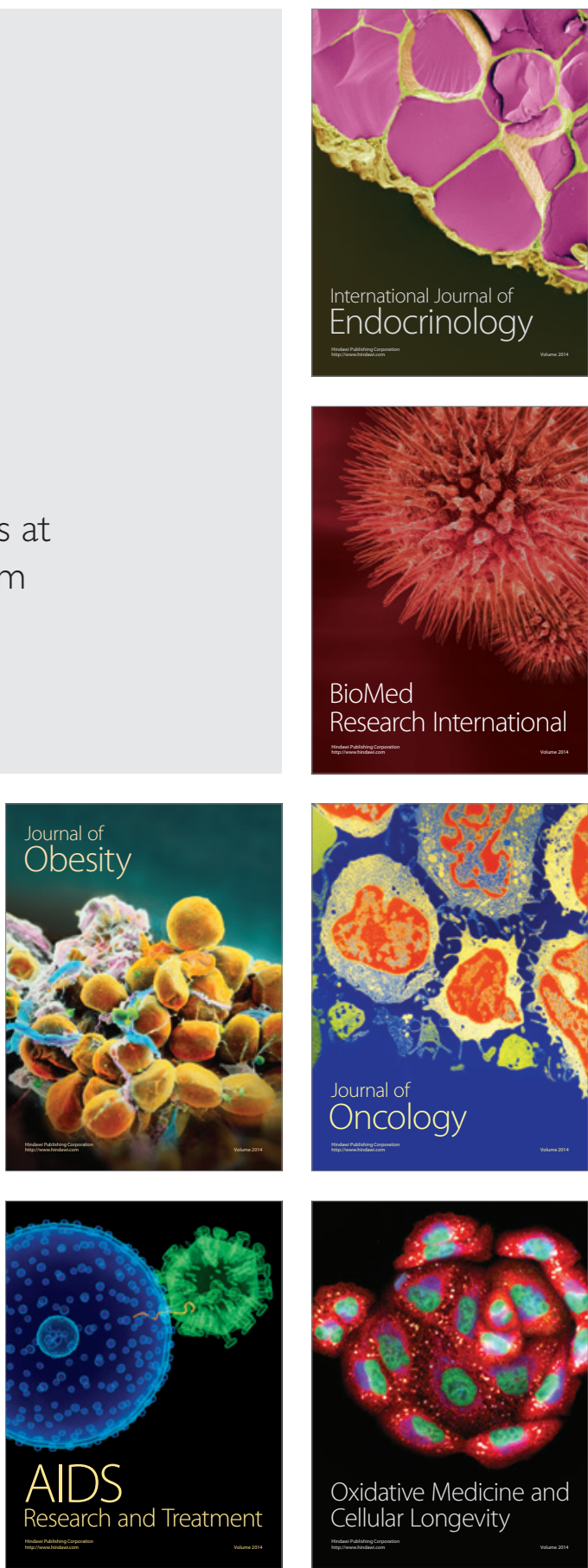